\title{
Penyusunan Balanced Scorecard pada PT Cipta Paramula Sejati
}

\section{Compilation of the Balanced Scorecard at PT Cipta Paramula Sejati}

\author{
Ines Pipit Yuniawati ${ }^{*}$, Heny K Daryanto ${ }^{2}$, Setiadi Djohar ${ }^{3}$ \\ 1) Program Pascasarjana Manajemen dan Bisnis, Sekolah Bisnis IPB Kampus IPB Gunung Gede Bogor 16151 \\ ${ }^{2)}$ Sekolah Bisnis, Institut Pertanian Bogor, Kampus IPB Gunung Gede Bogor 16151 \\ 3) PPM Manajemen, Menteng Raya 9 Jakarta 10340
}

\begin{abstract}
PT Cipta Paramula Sejati is one of the companies engaged in the space and office rental business in Jakarta. PT Cipta Paramula Sejati manages the rental of office buildings and rooms in the Jakarta Design Center Building. Jakarta Design Center is a mall that has three types of businesses related to building space rental. Every company will be faced with various problems, both problems that come from within the company (internal) and problems from outside the company (external). This study aims to analyze the strategic objectives and key performance indicator (KPI) in terms of four perspective Balanced Scorecard (BSC), an also performance measurement methods at PT Cipta Paramula Sejati based on BSC concept. The analytical method used is the BSC. The study used a descriptive approach through in-depth interviews with respondents who were chosen intentionally (purposive sampling). The results of the study obtained twelve strategic targets and fourteen KPI. Based on the results of the BSC compilation of PT Cipta Paramula Sejati, the weighting for each BSC perspective was as follows: financial perspective of 27.78 percent, customer perspective of 27.78 percent, internal business process perspective of 25 percent, and learning and growth perspective of 19.44 percent.
\end{abstract}

Keywords: building management, balanced scorecard, key performance indicator

\begin{abstract}
ABSTRAK
PT Cipta Paramula Sejati adalah salah satu perusahaan yang bergerak dalam bisnis penyewaan ruangan dan perkantoran di Jakarta. PT Cipta Paramula Sejati mengelola penyewaan gedung dan ruangan perkantoran di Gedung Jakarta Design Center. Jakarta Design Center merupakan mall yang memiliki tiga jenis usaha yang berkaitan dengan penyewaan ruangan gedung. Setiap perusahaan akan dihadapkan pada berbagai permasalahan, baik itu permasalahan yang berasal dari dalam perusahaan (internal) maupun permasalahan dari luar perusahaan (eksternal). Penelitian ini bertujuan untuk menganalisis sasaran strategis dan indikator yang menjadi tolak ukur kinerja ditinjau dari empat perspektif Balanced Scorecard (BSC), serta menyusun metode pengukuran kinerja di PT Cipta Paramula Sejati berdasarkan konsep BSC. Metode analisis yang digunakan adalah BSC. Penelitian menggunakan pendekatan deskriptif melalui wawancara secara mendalam dengan responden yang di pilih secara sengaja. Hasil penelitian diperoleh dua belas sasaran strategis dan empat belas tolak ukur kinerja. Berdasarkan hasil penyusunan BSC pada PT Cipta Paramula Sejati diperoleh pembobotan untuk masing- masing perspektif BSC adalah sebagai berikut: perspektif keuangan sebesar 27,78 persen, perspektif pelanggan sebesar 27,78 persen, perspektif proses bisnis internal sebesar 25 persen, dan perspektif pembelajaran dan pertumbuhan sebesar 19,44 persen.
\end{abstract}

Kata kunci : pengelola gedung, Balanced Scorecard, indikator tolak ukur kinerja.

*Corresponding author

Alamat e-mail: ipy3691@ gmail.com 


\section{PENDAHULUAN}

Pertumbuhan pembangunan gedung untuk perkantoran hampir meningkat setiap tahunnya, minimal dua gedung baru di setiap distrik atau wilayah bisnis di jalan utama Jakarta. Selama 2017, terdapat 12 gedung perkantoran baru yang dibangun di kawasan Cental Business District (CBD) Jakarta dan 11 di luar CBD (Colliers 2017). Iklim bisnis yang baik di Indonesia menarik minat investor untuk menanamkan investasinya, salah satunya adalah PT Cipta Paramula Sejati. PT Cipta Paramula Sejati mengelola penyewaan gedung dan ruangan perkantoran di Gedung Jakarta Design Center (JDC). JDC merupakan mall yang memiliki tiga jenis usaha yang berkaitan dengan penyewaan ruangan gedung. Pertama, menyediakan penyewaan ruangan bagi para tenant yang bergerak dalam bidang penjualan produk interior dan arsitektur. Kedua, menyediakan penyewaan ruangan kantor bagi para pengusaha yang bergerak dalam jasa desain interior dan arsitektur. Ketiga, menyediakan fasilitas ruangan yang fleksibel dan dilengkapi peralatan memadai untuk seminar, pameran, product launching, press conference dan dapat dimanfaatkan secara paralel (Trends 2007).

Persaingan sektor perkantoran di wilayah Jakarta semakin tinggi karena banyaknya pasokan perkantoran baru. Sejumlah proyek gedung perkantoran yang baru masuk pada 2018 semuanya berukuran sangat besar, seperti dua gedung baru di Central Business District yaitu Prosperity dan Treasury Tower. Jumlah pasokan kumulatif pada kuartal I-2018 di Jakarta adalah 6,2 juta meter persegi. Hal tersebut sudah termasuk kepada sekitar 470 ribu meter pesergi ruang perkantoran baru yang akan beroperasi sepanjang tahun 2018 (Suara 2018). Pertumbuhan pembangunan gedung baru untuk penyewaan perkantoran, ritel dan convention center, menuntut PT Cipta Paramula Sejati untuk dapat mengetahui kinerja atau performance perusahaan saat ini. Salah satu metode pengukuran kinerja yang tidak hanya mengukur kinerja dari segi finansial saja adalah Balanced Scorecard (BSC). Konsep pengukuran kinerja dengan BSC pertama kali dipublikasikan dalam artikel Robert S Kaplan dan David P Norton di Harvard Business Review tahun 1992 dalam sebuah artikel berjudul "Balanced Scoreard-Measures that Drive Performance". BSC memiliki empat kajian yang dilihat yaitu perspektif keuangan (financial), pelanggan (customers), bisnis internal (internal business), serta pembelajaran dan pertumbuhan (learning and growth) dengan target bersifat jangka panjang (Kaplan dan Norton 2000). Tujuan penelitian ini adalah untuk menganalisis sasaran strategi dan indikator yang menjadi tolak ukur kinerja (Key Performance Indicator/ KPI) ditinjau dari empat perspektif BSC, serta menyusun metode pengukuran kinerja di PT Cipta Paramula Sejati berdasarkan konsep BSC.

Beberapa penelitian dengan menggunakan BSC telah dilakukan diantaranya oleh Wulandari (2016) dengan judul Perancangan Sistem BSC pada Perusahaan Properti (Studi Kasus: Elang Group). Hasil penelitian diperoleh delapan faktor internal dan lima faktor eksernal perusahaan yang berpengaruh terhadap strategi perusahaan, dan berdasarkan hasil pembobotan, indikator ROI mendapat bobot tertinggi terhadap keseluruhan kinerja yakni sebesar 19,7 persen. Fauziah (2007) melakukan penelitian dengan judul perancangan dan pengukuran kinerja dengan pendekatan BSC di PT Karisma Dutawasera regional Bandung. Penelitian tersebut menggunakan metode analisis analisis deskriptif, analisis kuantitatif BSC, paired comparison dan performance range. Secara keseluruhan total kinerja perusahaan adalah sangat baik dengan indeks kinerja sebesar 107,27 persen. Arief HW (2007) meneliti perancangan pengukuran kinerja pada PT Mitrarahayu Karyanugraha dengan menngunakan alat analisis BSC. Hasil penelitian diperoleh perspektif keuangan sebagai perspektif yang paling penting yaitu sebesar 34,4 persen.

Penelitian yang dilakukan di luar negeri mengenai BSC diantaranya adalah Abdel dan Saed (2014) mengenai penggunaan BSC pada manufaktur farmasi di Jordania. Hasil penelitian menjelaskan perspektif pelanggan memberikan dampak langsung terhadap kinerja manufaktur farmasi di Jordania. Ayoup H et al. (2016) menganalisis penggunaan BSC untuk meningkatkan proses penyelarasan strategi pada perusahaan besar Malaysian Government-Link Company (GLC). Hasil penelitian diperoleh BSC terbukti dapat membantu meningkatkan proses penyelarasan strategi perusahaan. Chih chao Chung et al. (2016) meneliti perusahaan sepeda di Taiwan, penelitian ini menganalisis kaitan anatara empat prespektif BSC dengan prespektif 
sustainable management. Hasil penelitian menyatakan bahwa indikator yang menjadi fokus utama untuk tercapainya sustainable managemnet adalah indikator prespektif keuangan. Martello M et al. (2016) menerapkan penggunaan BSC pada organisasi non-for-profit di Amerika Serikat. Hasil penelitian menunjukkan bahwa penerapan BSC juga efektif dilakukan pada organisasi nonfor-profit, dimana dengan bantuan BSC, organisasi dapat mengetahui lebih lengkap dan komprehensif mengenai kondisi perusahaan. Chimtengo S et al. (2017) melakukan pengukuran kinerja dengan menggunakan BSC di University of Malawi Polytechnic. Hasil kinerja keempat perspektif BSC adalah buruk.

Penerapan konsep BSC dalam setiap organisasi perusahaan disesuaikan dengan kondisi dan karakteristik masing-masing perusahaan. Perbedaan penelitian ini terhadap penelitian BSC terdahulu adalah perusahaan yang menjadi objek penelitian dan ukuran kinerja dalam empat perspektif BSC yang digunakan. Objek yang digunakan dalam penelitian ini adalah PT Cipta Paramula Sejati, yaitu perusahaan yang mengelola penyewaan gedung untuk kantor, pusat perbelanjaan, dan seminar, dimana belum ada penelitian terdahulu yang melakukan penelitian penyusunan BSC pada perusahaan tersebut.

\section{Tinjauan Pustaka}

Konsep Pusat Perbelanjaan Modern

Tenant adalah penyewa ruangan yang akan digunakan untuk melakukan proses jual beli antara penyewa di mall dengan pengunjung yang akan datang ke mall. Konsep pusat perbelanjaan modern merujuk pada sekolompok kesatuan pusat perdagangan yang dibangun dan didirikan pada sebuah lokasi yang direncanakan, dikembangkan, dan diatur menjadi sebuah kesatuan operasi (operation mix), berhubungan dengan lokasi, ukuran, tipe toko, dan area perbelanjaan dari unit tersebut. Unit ini juga menyediakan parkir yang dibuat berhubungan dengan tipe dan ukuran total toko- toko (Trijaya 2010).

Konsep Manajemen Strategis yaitu:

David (2006) mengungkapkan terdapat tiga tahapan dalam proses manajemen strategi,

1. Formulasi Strategi: membangun misi bisnis, identifikasi peluang dan ancaman eksternal, menentukan kekuatan dan kelemahan internal, menentukan tujuan jangka panjang, mengembangkan strategi alternatif, dan menentukan suatu strategi tertentu untuk diterapkan

2. Implementasi Strategi (Tahap Aksi): penetapan tujuan tahunan, menerapkan kebijakan, memotivasi karyawan, dan mengalokasikan sumberdaya, sehingga strategi yang telah ditetapkan dapat dijalankan; termasuk pula pengembangan budaya perusahaan, struktur organisasi, pemasaran, penganggaran, sistem informasi, dan sistem kompensasi.

3. Evaluasi Strategi: tinjauan ulang kondisi eksternal dan internal, mengukur kinerja, dan menerapkan langkah koreksi.

Konsep BSC

BSC sebagai suatu sistem manajemen mengintegrasikan visi, misi dan strategi kedalam empat perspektif secara seimbang. Kerangka kerja BSC berawal dari perspektif pembelajaran dan pertumbuhan. Dalam perspektif ini terdapat tiga kategori utama yaitu human capital, information capital dan organization capital. Sasaran utama perspektif pembelajaran dan pertumbuhan adalah human capital atau pembangunan manusia. Kemudian perspektif proses bisnis internal; perspektif ini merupakan proses internal untuk memenuhi nilai bagi pelanggan dan pemilik usaha. Sasaran utama perspektif proses bisnis internal adalah untuk menciptakan nilai bagi pelanggan dan memberikan hasil keuangan yang baik. Selanjutnya adalah perspektif konsumen; sasaran utama perspektif ini adalah profitabilitas pelanggan. Tahap terakhir adalah perspektif keuangan dengan fokus utama adalah peningkatan laba perusahaan. Alur kerangka kerja BSC dapat dilihat pada Gambar 1 (Kaplan dan Norton 2000).

Jurnal Manajemen dan Organisas

(JMO),

Vol. 9 No. 3 ,

Desember 2018 


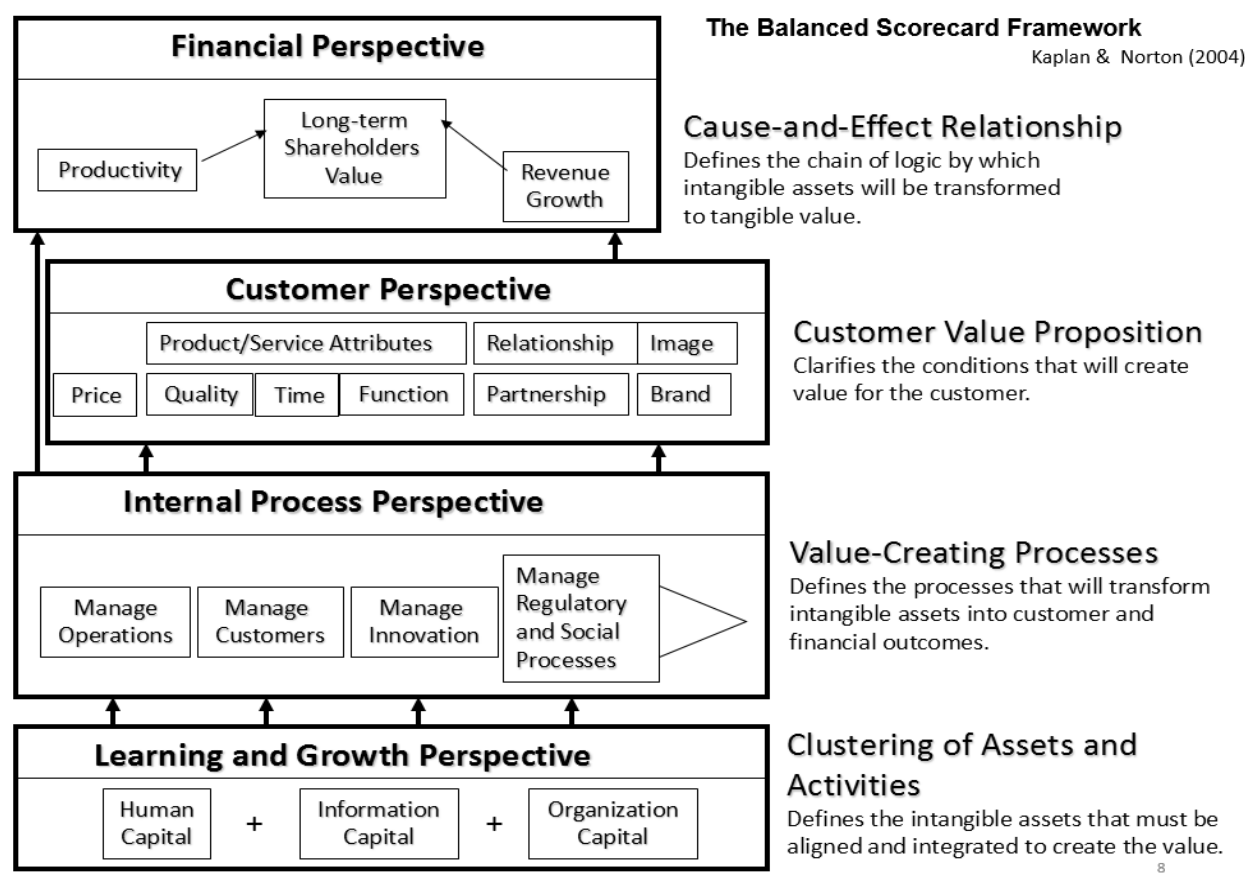

Gambar 1. Kerangka Kerja BSC

Sumber: Kaplan dan Norton (2000)

\section{a. Perspektif Keuangan (Financial)}

Perspektif keuangan memberikan petunjuk apakah strategi perusahaan, implementasi dan pelaksanaannya memberikan kontribusi terhadap peningkatan laba perusahaan yang menjadi fokus tujuan serta ukuran di semua perspektif scorecard. Bagi sebagian perusahaan, tema keuangan berupa peningkatan pendapatan, penurunan biaya dan peningkatan produktifitas, peningkatan pemanfaatan aktiva dan penurunan resiko dapat menghasilkan keterkaitan yang diperlukan diantara keempat perspektif scorecard (Kaplan dan Norton 2000). Faktor pendorong tercapainya tujuan jangka panjang dalam perspektif keuangan harus disesuaikan menurut jenis industri, lingkungan persaingan dan strategi di setiap unit bisnis yang disederhanakan dalam tiga tahap siklus hidup bisnis, yaitu (1) bertumbuh, (2) bertahan, dan (3) menuai.

b. Perspektif Pelanggan (customer)

Pelanggan adalah siapa saja yang menggunakan produk atau jasa yang dihasilkan oleh perusahaan. Perspektif pelanggan mendefinisikan pelanggan dan segmen pasar dimana unit bisnis akan bersaing dalam berbagai ukuran kinerja di dalam segmen sasaran. Tolak ukur kinerja yang digunakan dalam perspektif pelanggan dikelompokkan dalam suatu mata rantai hubungan sebab akibat (Gambar 2) (Kaplan dan Norton 2000).

Komponen dari tolak ukur perspektif pelanggan adalah sebagai berikut:

1. Kepuasan pelanggan: menunjukkan terpenuhinya harapan pelanggan terhadap produk atau jasa.

2. Retensi pelanggan: menunjukkan seberapa baik usaha perusahaan untuk mempertahankan pelanggannya.

3. Akuisisi pelanggan: mengukur dalam bentuk relatif atau absolut keberhasilan unit bisnis untuk menarik atau memenangkan pelanggan atau bisnis baru.

4. Pangsa Pasar: menggambarkan proporsi bisnis yang dijual oleh sebuah unit bisnis di pasar tertentu (dalam bentuk jumlah pelanggan, uang yang dibelanjakan, atau volume satuan yang terjual).

5. Profitabilitas pelanggan: mengukur keuntungan bersih yang dapat diperoleh dari pelanggan setelah menghitung berbagai pengeluaran yang digunakan untuk memenuhi kebutuhan pelanggan. 


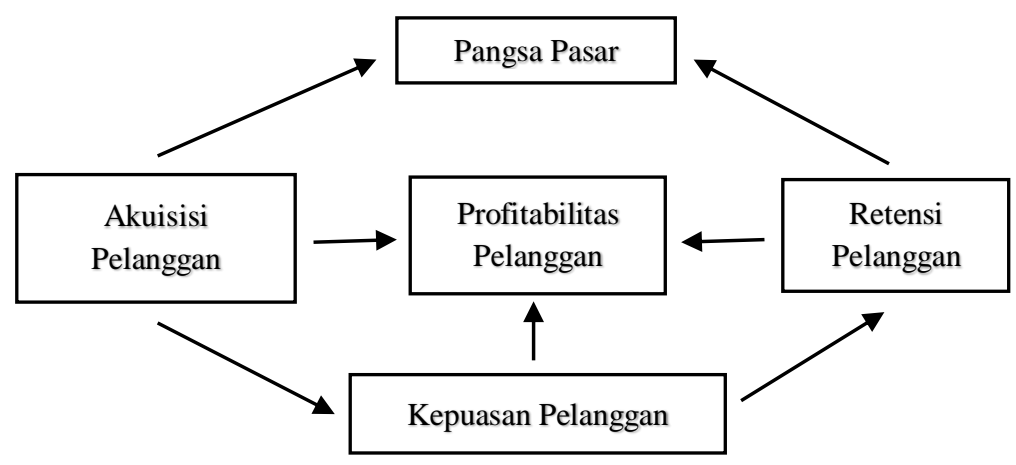

Gambar 2. Ukuran utama perspektif pelanggan

Sumber: Kaplan dan Norton (2000)

\section{c. Perspektif Proses Bisnis Internal}

Proses bisnis internal merupakan proses internal untuk memenuhi nilai bagi pelanggan dan pemilik perusahaan. Proses bisnis internal dalam BSC merupakan serangkaian proses tertentu untuk menciptakan nilai bagi pelanggan dan memberikan hasil keuangan yang baik. Model rantai nilai terdiri dari tiga proses bisnis utama, seperti ditunjukkan pada Gambar 3.

\section{Proses Inovasi \\ Proses Operasi \\ Proses \\ Layanan}

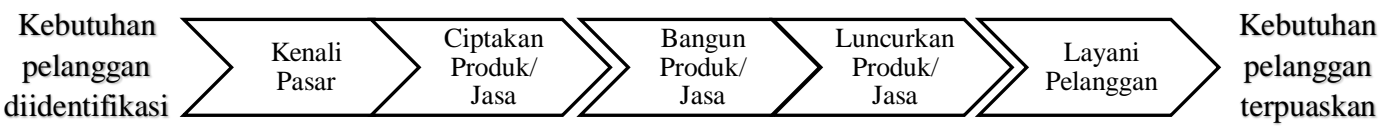

Gambar 3. Model rantai nilai Sumber: Kaplan dan Norton (2000)

1. Inovasi

Proses inovasi dilakukan untuk meneliti kebutuhan pelanggan yang sedang berkembang atau yang masih tersembunyi. Unit bisnis kemudian menciptakan produk atau jasa untuk memenuhi kebutuhan tersebut.

2. Operasi

Pelaksanaan operasi dimulai ketika perusahaan memulai menerima pesanan dari pelanggan dan berakhir pada penyampaian produk atau jasa kepada pelanggan. Proses ini menitikberatkan kepada penyampaian produk atau jasa kepada pelanggan secara efisien dan konsisten.

3. Layanan Purna Jual

Layanan purna jual menghasilkan nilai tambah bagi keseluruhan proses operasi bisnis internal. Perusahaan menyediakan layanan kepada pelanggan setelah menerima produk atau jasa yang dibeli. Layanan ini mencakup garansi dan aktivitas perbaikan, penggantian produk, serta proses pembayaran seperti administrasi kartu kredit.

d. Perspektif Pembelajaran dan Pertumbuhan

Tiga sumber utama pembelajaran dan pertumbuhan perusahaan, yaitu manusia, sistem dan prosedur perusahaan. Kaplan dan Norton (2000) mengemukakan tiga kategori utama dalam perspektif pembelajaran dan pertumbuhan, yaitu:

1. Kapabilitas Karyawan

Kapabilitas pekerja dapat diukur melalui kepuasan pekerja, tingkat retensi, pelatihan dan keahlian pekerja ditambah faktor pendorongnya, seperti indeks khusus yang terperinci mengenai keahlian spesifik yang dibutuhkan bagi lingkungan kompetitif baru.

2. Kapabilitas Sistem Informasi

Ukuran yang berorientasi kepada kapabilitas sistem informasi meliputi tersedianya informasi tepat waktu dan akurat mengenai pelanggan dan proses bisnis internal yang penting bagi para pengambil keputusan. 
3. Motivasi, pemberdayaan dan keselarasan.

Motivasi pekerja dapat dinilai sebanding dengan banyaknya saran yang diberikan per pekerja, diperkuat dengan jumlah saran yang dilaksanakan, menilai mutu saran yang diajukan dan mengkomunikasikan kepada karyawan bahwa saran-saran mereka dihargai dan diperhatikan.

Pembangunan sumberdaya manusia menjadi sasaran utama perspektif pembelajaran dan pertumbuhan. Hal tersebut dikarenakan sumberdaya manusia menjadi faktor pembeda perusahaan dalam persaingan, melalui kemampuan mereka menerapkan pengetahuan dalam pekerjaan. Selain itu, sumberdaya manusia merupakan subjek pelaku utama yang menjadi motor penggerak bagi pencapaian sasaran-sasaran yang terhierarki hingga kepada sasaran akhir keuangan perusahaan.

Kerangka Konseptual

Penelitian ini dimulai dari identifikasi visi dan misi PT Cipta Paramula Sejati. Identifikasi visi dan misi dilakukan untuk mentukan sasaran strategi dan key performance indikator (KPI) berdasarkan empat perspektif BSC, yaitu perspektif keuangan, perspektif pelanggan, perspektif proses internal bisnis, dan perspektif pembelajaran dan pertumbuhan. Hasil dari sasaran strategis digunakan untuk membuat peta strategi perusahaan. Tahapan selanjutnya adalah menyusun rancangan BSC dan melakukan pembobotan BSC. Pembobotan terhadap sasaran strategi dan KPI dilakukan dengan metode paired comparison untuk melihat seberapa jauh tingkat kontribusi dari masing-masing perspektif pada BSC. Tahap akhir adalah melakukan simulasi sederhana mengenai pencapaian penyusunan sistem BSC. Secara sistematis, kerangka pemikiran operasional penelitian dapat dilihat pada Gambar 4.

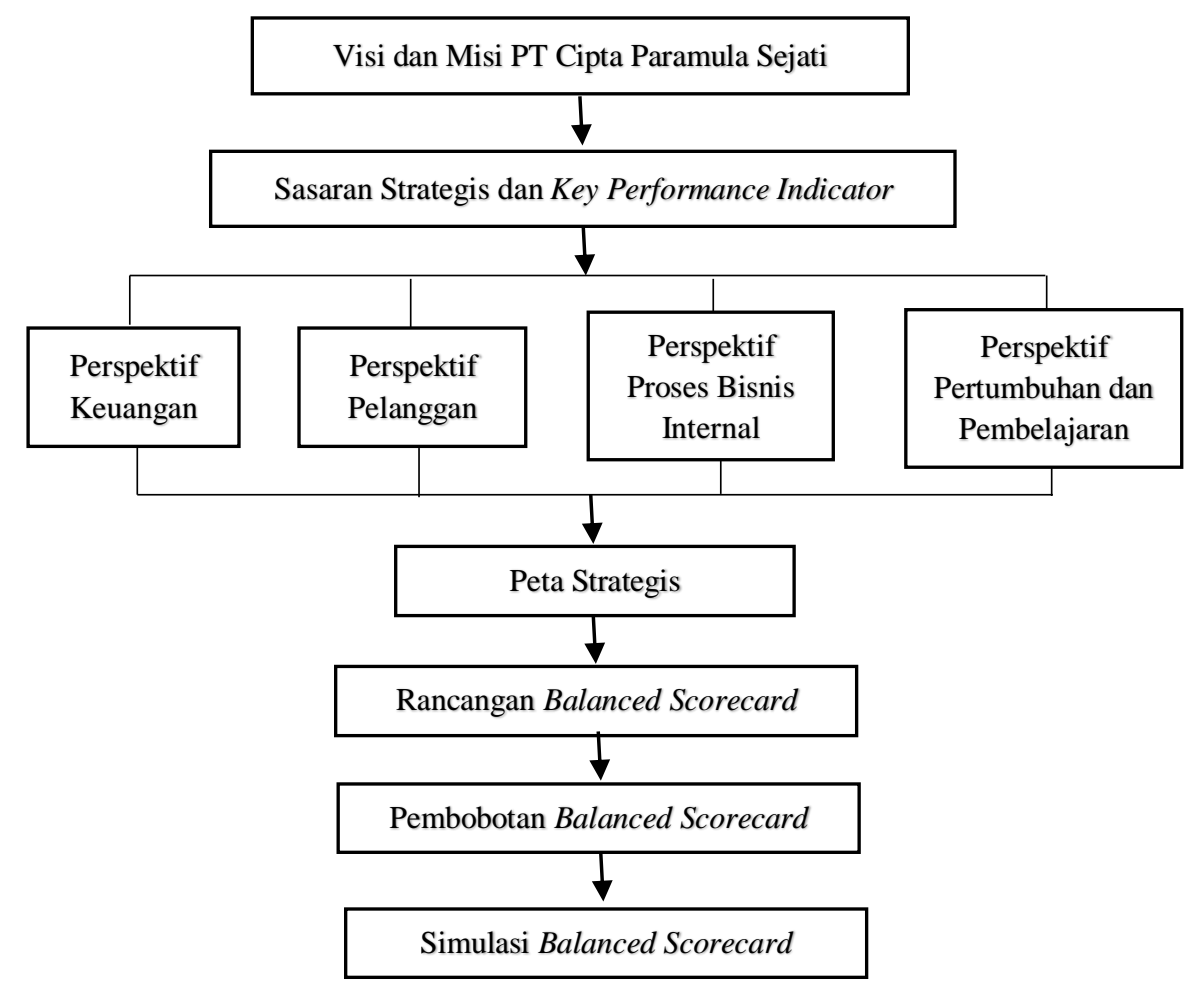

Gambar 4. Kerangka Pemikiran Konseptual

\section{METODE PENELITIAN}

Penelitian ini dilakukan di PT Cipta Paramula Sejati, yang berlokasi di Jalan Jendral Gatot Subroto 53, Slipi - Jakarta 10260. Pemilihan lokasi dilakukan secara sengaja (purposive) berdasarkan pada satu-satunya perusahaan yang bergerak dibidang pengelolaan gedung untuk penyewaan ruang berbentuk pusat perbelanjaan atau mall. Penelitian dilakukan pada tahun 2017.

Jurnal Manajemen dan Organisasi (JMO),

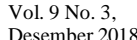
Desember 2018 Hal. $149-162$ 
Penelitian menggunakan dua jenis data, yaitu data primer dan data sekunder. Data primer, diperoleh langsung dari responden melalui wawancara dan observasi pada beberapa key informant yang telah dipilih secara sengaja (purposive). Jumlah responden adalah lima responden yang terdiri dari empat Senior Manager (Manager Pemasaran, Manager Umum dan Personalia, Manager Keuangan, dan Manager Teknik) dan satu Senior Kepala Bagian (Kepala Bagian Akunting). Responden yang dipilih dianggap memiliki pengetahuan mendalam mengenai PT Cipta Paramula Sejati. Data sekunder, diperoleh dalam bentuk arsip, data laporan perusahaan, jurnal dan internet.

Tahapan dan metode analisis penelitian dilakukan berdasrakan tahapan pembentukan BSC berdasarkan Niven (2006) yaitu:

1. Penentuan sasaran strategi dan KPI diperoleh melalui wawancara mendalam (in-depth interview) kepada responden yang telah di tetapkan sebelumnya (purposive sampling). KPI disusun berdasarkan prinsip SMART- C (Spesific, Measureable, Achivement, Relevant, Timebounded dan Continuously).

2. Pembentukan Peta Strategis Perusahaan

3. Penentuan Target KPI dan Inisiatif Strategi

Penentuan KPI dan Skor dilakukan oleh responden, kemudian hasilnya diolah peneliti. Tahap selanjutnya adalah menentuan Target dan Inisiatif Strategi. Target merupakan suatu ukuran yang ingin dicapai dalam jangka waktu tertentu, sedangkan Inisiatif Strategi (IS) merupakan suatu kegiatan atau beberapa langkah kegiatan yang digunakan sebagai cara untuk mencapai target KPI. Penetapan target dan inisiatif strategi dari masing- masing KPI diserahkan kepada pihak PT Cipta Paramula Sejati sesuai dengan kebijakan dan kesepakatan perusahaan.

4. Penyusunan rancangan BSC

Tabel 1. Kerangka Rancangan BSC

\begin{tabular}{llccc}
\multicolumn{1}{c}{ Perspektif } & $\begin{array}{c}\text { Sasaran } \\
\text { Strategi }\end{array}$ & $\begin{array}{c}\text { Key Performance } \\
\text { Indicators }\end{array}$ & Target & $\begin{array}{c}\text { Inisiatif } \\
\text { Strategis }\end{array}$ \\
\hline $\begin{array}{l}\text { Keuangan } \\
\text { Pelanggan }\end{array}$ & & & \\
Proses Bisnis Internal & & & \\
Pembelajaran dan Pertumbuhan & & & \\
\hline
\end{tabular}

\section{Pembobotan KPI}

Pembobotan dilakukan menggunakan metode paired comparison. Menurut Kinner dan Taylor (1991), metode paired comparison digunakan untuk menentukkan bobot setiap indikator pada keempat perspektif BSC berdasarkan tingkat kepentingan perusahaan. Penentuan bobot dilakukan dengan mengajukan identifikasi kepada sumber ahli melalui pemberian wawancara kuisioner. Bobot setiap indikator diperoleh dengan menentukkan nilai setiap indikator terhadap nilai jumlah keseluruhan berdasarkan ketentuan rumus sebagai berikut:

$$
\left[a_{i}=\frac{x_{i}}{\sum_{i}^{n} x_{i}}\right]
$$

Keterangan : a : bobot indikator ke-i

$\mathrm{X}_{\mathrm{i}}$ : nilai indikator ke-i

i : $1,2,3, \ldots, n$

$\mathrm{n}:$ jumlah indikator

Tabel 2. Pembobotan Key Performance Indicator dengan paired comparison

\begin{tabular}{|c|c|c|c|c|}
\hline KPI & A & B & C & D \\
\hline A & & & & \\
\hline B & & & & \\
\hline C & & & & \\
\hline D & & & & \\
\hline
\end{tabular}

Metode ini menunjukkan perbandingan nilai antara indikator (horizontal-vertikal) dalam skala 1,2,3,4 atau 5 sebagai berikut:

Nilai 1 = faktor horizontal tidak penting daripada faktor vertikal

Nilai 2 = faktor horizontal kurang penting daripada faktor vertikal 
Nilai 3 = faktor horizontal sama penting daripada faktor vertikal

Nilai 4 = faktor horizontal lebih penting daripada faktor vertikal

Nilai 5 = faktor horizontal sangat penting daripada faktor vertikal

Dengan asumsi:

a. Jika perbandingan indikator $A$ terhadap $B=5$, maka perbandingan indikator $B$ terhadap $A=1$, yaitu indikator $A$ sangat penting daripada indikator $B$ atau indikator $B$ tidak penting daripada $A$. b. Jika perbandingan indikator $A$ terhadap $B=4$, maka perbandingan indikator $B$ terhadap $A=2$, yaitu indikator $\mathrm{A}$ lebih penting daripada indikator $\mathrm{B}$ atau indikator $\mathrm{B}$ kurang penting daripada $\mathrm{A}$. c. Jika perbandingan indikator $A$ terhadap $B=3$, maka perbandingan indikator $B$ terhadap $A=3$, yaitu indikator A dan indikator B sama penting.

Bobot KPI yang tertinggi akan menjadi tanggung jawab level manajemen yang tertinggi, sedangkan bobot KPI yang terendah akan menjadi tanggung jawab bagian-bagian tiap manajemen.

6. Simulasi BSC

Tahap terakhir adalah melakukan simulasi BSC secara sederhana dengan menggunakan Microsoft Excel. Simulasi dilakukan dengan membandingkan antara bobot pencapaian masingmasing KPI dengan nilai bobot dari masing- masing perspektif. Bobot pencapaian diperoleh dari bobot masing-masing KPI dibagi bobot keseluruhan masing-masing persepektif dikali seratus persen.

\section{HASIL DAN PEMBAHASAN}

\section{Sasaran Straegis dan Key Performance Incicator (KPI) PT Cipta Paramula Sejati}

Sasaran strategis merupakan kondisi ideal tertentu yang ingin diraih oleh perusahaan dimasa yang akan datang dengan menggunakan strategi- strategi yang telah ditetapkan sebelumnya berdasarkan berbagai pertimbangan yang ada. Adapun sasaran strategis dan KPI PT Cipta Paramula Sejati pada setiap perspektif $B S C$ diuraikan sebagai berikut:

Perspektif Keuangan

Sasaran perspektif keuangan perusahaan terdiri dari peningkatan posisi keuangan, pertumbuhan profitabilitas, dan peningkatan perputaran aset. Data yang digunakan untuk pengukuran perspektif keuangan adalah data keuangan perusahaan tahun 2014, 2015 dan 2016. KPI yang ditetapkan pada sasaran strategis peningkatan posisi keuangan adalah Gross Profit Margin (GPM). KPI untuk sasaran strategis pertumbuhan profitabilitas adalah Return On Investement (ROI) dan Net Profit Margin (NPM). KPI untuk sasaran strategis peningkatan perputaran asset adalah dan Return On Assets (ROA). Hasil perhitungan KPI PT Cipta Paramula Sejati pada perspektif keuangan dapat dilihat pada Tabel 3 .

Tabel 3. Perhitungan KPI perspektif keuangan

\begin{tabular}{|c|c|c|c|c|}
\hline & $(\%)$ & 2014 & 2015 & 2016 \\
\hline GPM & $\frac{\text { Laba Kotor }}{\text { Penjualan Bersih }}$ & 75,25 & 75,27 & 76,41 \\
\hline ROI & $\frac{\text { Laba Bersih }}{\text { Total Aktiva }}$ & 28,62 & 27,81 & 26,68 \\
\hline NPM & $\frac{\text { Laba Bersih }}{\text { Penjualan Bersih }}$ & 39,40 & 38,58 & 37,33 \\
\hline ROA & $\frac{\text { Laba Sebelum Pajak }}{\text { Aktiva }}$ & 35,88 & 34,85 & 33,79 \\
\hline
\end{tabular}

Sumber: Laporan Laba Rugi PT Cipta Paramula Sejati diolah 2017 
Berdasarkan hasil perhitungan dapat dilihat bahwa hanya KPI GPM yang mengalami peningkatan. Peningkatan maupun penurunan persentase nilai KPI hanya sebesar satu persen pertahun. Berdasarkan pada hasil wawancara dengan responden manager keuangan dan kepala bagaian keuangan target keuntungan yang ditetapkan PT Cipta Paramula Sejati adalah minimal sebesar 10 persen.

Perspektif Pelanggan

Berdasarkan hasil identifikasi sasaran strategis pada perspektif pelanggan ditetapkan tiga sasaran strategis, yaitu: kepuasan pelanggan, loyalitas pelanggan, dan peningkatan Brand Image perusahaan. Jenis pelanggan pada PT Cipta Paramula Sejati adalah perusahaan-perusahaan atau asosiasi yang kemudian disebut sebagai tenant. Adapun KPI yang ditetapkan untuk masingmasing sasaran strategis pada perspektif pelanggan adalah sebagai berikut:

KPI pada sasaran strategis kepuasan pelanggan adalah indeks kepuasan pelanggan. Rumus untuk menghitung persentase pelanggan yang puas dengan produk dan layanan PT Cipta Paramula Sejati adalah sebagai berikut:

Persentase pelanggan yang puas $=\frac{\text { Jumlah pelanggan yang puas }}{\text { jumlah keseluruhan pelanggan }} \times 100 \%$

Jumlah keseluruhan pelanggan di PT Cipta Paramula Sejati adalah sebanyak 60 pelanggan dengan jumlah pelanggan yang puas sebanyak 54 pelanggan, maka diperoleh persentasi pelanggan yang puas sebesar 90 persen. Berdasarkan pada hasil wawancara diperoleh KPI pada sasaran strategis loyalitas pelanggan adalah rating loyalitas pelanggan. Rating loyalitas pelanggan diperoleh melalui perhitungan jumlah pelanggan yang loyal tahun ini dikurangi jumlah pelanggan loyal tahun sebelumnya dibagi pelanggan loyal tahun lalu. Sistem perhitungan loyalitas pelanggan pada PT Cipta Paramula Sejati dilakukan setelah masa kontrak pelanggan dalam hal ini tentant habis masa, jangka masa kontrak tenant adalah lima tahun. KPI pada sasaran strategis peningkatan brand image adalah brand image. Brand image terbentuk dari pengalaman pelanggan terhadap citra yang terbentuk dari produk dan layanan yang diberikan oleh perusahaan. Produk yang terdapat pada PT Cipta Paramula Sejati merupakan produk yang memiliki brand image yang luxurious dan exclusive.

Perspektif Proses Bisnis Internal

Proses bisnis utama yang dilakukan PT Cipta Paramula Sejati adalah penyewaan ruang untuk kegiatan bisnis. Sasaran strategis perspektif proses bisnis internal adalah peningkatan kualitas pelayanan, optimalisasi pengoperasian ruangan yang efektif, dan peningkatan aktivitas promosi dan inovatif. Adapun KPI yang ditetapkan perusahaan adalah jumlah keluhan pelanggan, jumlah ruang yang disewakan, dan jumlah program marketing pertahun. Adapun indikator pemicu (lead indicator) yang dapat digunakan adalah: pengurangan pengaduan dan kecepatan waktu respon terhadap permintaan pelanggan, rencana pemasaran dan rencana keuangan. PT Cipta Paramula sejati memiliki sistem operasional yang sangat baik, hal ini dapat terlihat pada rendahnya tingkat keluhan pelanggan, dan optimalnya penggunaan jumlah ruang yang disewakan. PT Cipta Paramula Sejati memiliki daftar waiting list pelanggan, hal ini membuat jumlah program promosi menjadi tidak begitu banyak jumlahnya.

Perspektif Pembelajaran dan Pertumbuhan

PT Cipta Paramula sejati dalam perspektif pembelajaran dan pertumbuhan memfokuskan pada sumberdaya manusia atau karyawan di perusahaan. Perspektif pembelajaran dan pertumbuhan merupakan pondasi dalam BSC. Oleh karena itu PT Cipta Paramula Sejati memerlukan sumberdaya manusia yang dapat melaksankan fungsi kerja dengan efektif dan efisien. Sasaran strategis yang ditetapkan adalah peningkatan komitmen dan loyalitas karyawan, peningkatan kualitas dan kapabilitas karyawan, serta optimalisasi penggunaan teknologi untuk penunjang operasional perusahaan. KPI untuk sasaran strategi peningkatan komitmen dan loyalitas karyawan adalah tingkat kepuasan personal karyawan dan tingkat kehadiran karyawan. Menurut Norton dan Kaplan (2000), terdapat beberapa elemen dari kepuasan karyawan yaitu: (1) keterlibatan dalam pengambilan keputusan, (2) pengakuan atas pekerjaan yang baik, (3) akses kepada informasi yang cukup untuk bekerja dengan baik, (4) dorongan aktif agar kreatif dan menggunakan inisiatif, (5) dukungan atasan dan (6) kepuasan menyeluruh terhadap perusahaan. 
KPI untuk sasaran strategi peningkatan kualitas dan kapabilitas karyawan adalah produktivitas karyawan. Pengukuran tingkat kepuasan personel karyawan, tingkat kehadiran karyawan, dan produktivitas karyawan dilakukan dengan survei kepuasan karyawan, turnover karyawan dan laporan absensi karyawan. KPI untuk sasaran strategi optimasi penggunaan teknologi untuk penunjang operasi perusahaan adalah menghitung jumlah visitor yang melakukan kunjungan ke website perusahaan.

\section{Peta Strategis PT Cipta Paramula Sejati}

Menurut Kaplan dan Norton (2004), peta strategi menggambarkan bagaimana organisasi menciptakan nilai dengan cara menghubungkan sasaran strategi yang terdapat pada empat perspektif BSC. Dengan menyusun peta strategi terlebih dahulu akan memudahkan perusahaan dalam menjalankan strategi-strategi yang direncanakan dengan efektif dan efisien. Pembentukan peta strategi PT Cipta Paramula Sejati menggunakan empat perspektif dengan format yang biasa digunakan, yaitu: perspektif keuangan, perspektif pelanggan, perspektif proses bisnis internal, serta perspektif pembelajaran dan pertumbuhan.

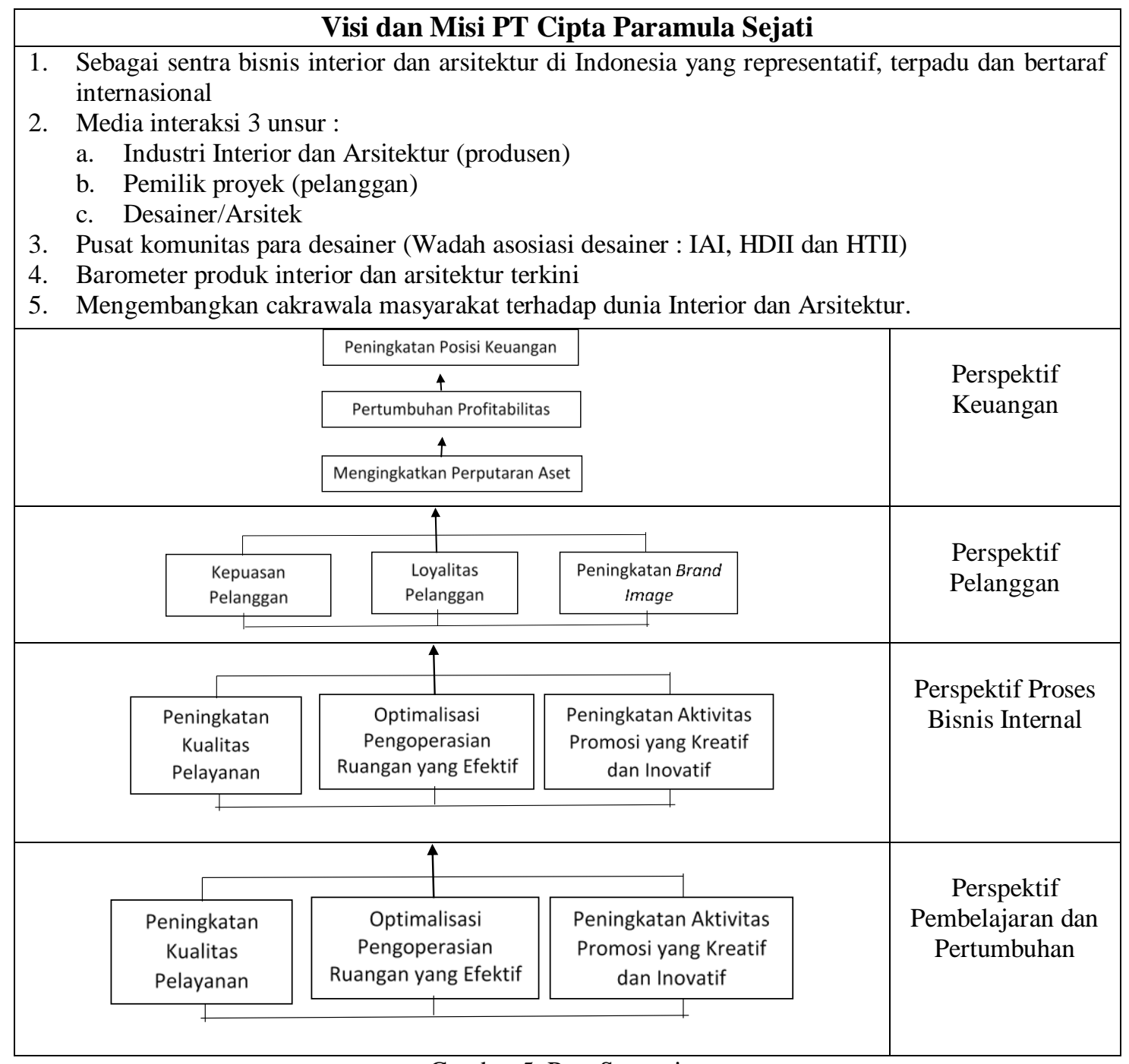

Gambar 5. Peta Strategis

\section{Target KPI, Inisiatif Strategis, dan Rancangan BSC}

Penentuan target KPI dan Inisiatif Strategi diserahkan kepada pihak PT Cipta Paramula Sejati atau ditetapkan oleh perusahaan. Nilai target ditetapkan setiap tahunnya oleh manager divisi perusahaan. Adapun rancangan BSC dapat dilihat pada Tabel 4. 
Tabel 4. Rancangan Matriks BSC

\begin{tabular}{|c|c|c|c|c|}
\hline \multirow[t]{2}{*}{ Sasaran Strategis } & \multicolumn{2}{|c|}{ Key Performance Indikator (KPI) } & \multirow{2}{*}{$\begin{array}{c}\text { Target } \\
\text { (Persen) }\end{array}$} & \multirow[t]{2}{*}{ Inisiatif Strategis } \\
\hline & Lag Indicator & Lead Indicator & & \\
\hline \multicolumn{5}{|c|}{ PERSPEKTIF FINANSIAL } \\
\hline Peningkatan posisi & - GPM & - Nilai laba bersih & Minimal 10 & - Penggunaan \\
\hline keuangan & & $\begin{array}{l}\text { - Nilai penjualan } \\
\text { bersih }\end{array}$ & Minimal 10 & $\begin{array}{l}\text { dana secara } \\
\text { efisien }\end{array}$ \\
\hline Pertumbuhan & - Net Profit & - Nilai aktiva & & - Meningkatkan \\
\hline Profitabilitas & Margin & $\begin{array}{l}\text { - Sales growth } \\
\text { percentage }\end{array}$ & & $\begin{array}{l}\text { profitabilitas } \\
\text { dan perputaran }\end{array}$ \\
\hline $\begin{array}{l}\text { Peningkatan perputaran } \\
\text { aset }\end{array}$ & - ROA & & Minimal 10 & \\
\hline \multicolumn{5}{|c|}{ PERSPEKTIF PELANGGAN } \\
\hline Kepuasan pelanggan & $\begin{array}{l}\text { - Indeks } \\
\text { kepuasan } \\
\text { pelanggan }\end{array}$ & $\begin{array}{l}\text { - Pemenuhan } \\
\text { kebutuhan } \\
\text { pelanggan }\end{array}$ & Diatas 80 & $\begin{array}{l}\text { - Meningkatkan } \\
\text { promosi } \\
\text { • Meningkatkan }\end{array}$ \\
\hline Loyalitas pelanggan & $\begin{array}{l}\text { - Rating } \\
\text { loyalitas } \\
\text { pelanggan }\end{array}$ & $\begin{array}{l}\text { - Komposisi jenis } \\
\text { usaha tenant }\end{array}$ & Diatas 80 & $\begin{array}{l}\text { sistem reward } \\
\text { dan punishment } \\
\text { pelanggan }\end{array}$ \\
\hline $\begin{array}{l}\text { Meningkatkan Brand } \\
\text { Image }\end{array}$ & - Brand Image & & Diatas 80 & \\
\hline \multicolumn{5}{|c|}{ PERSPEKTIF BISNIS INTERNAL } \\
\hline $\begin{array}{l}\text { Meningkatkan kualitas } \\
\text { pelayanan }\end{array}$ & $\begin{array}{l}\text { - Jumlah } \\
\text { keluhan } \\
\text { pelanggan }\end{array}$ & $\begin{array}{l}\text { - Pengurangan } \\
\text { pengaduan dan } \\
\text { kecepatan waktu } \\
\text { respon terhadap } \\
\text { permintaan } \\
\text { pelanggan }\end{array}$ & Diatas 90 & $\begin{array}{l}\text { - Efektivitas dan } \\
\text { efisiensi produk/ } \\
\text { jasa yang } \\
\text { ditawarkan PT } \\
\text { Cipta Paramula } \\
\text { Sejati }\end{array}$ \\
\hline $\begin{array}{l}\text { Optimalisasi } \\
\text { pengoperasian ruangan } \\
\text { yang efektif }\end{array}$ & $\begin{array}{l}\text { - Jumlah ruang } \\
\text { yang } \\
\text { disewakan }\end{array}$ & $\begin{array}{l}\text { - Rencana pemasaran } \\
\text { - Rencana keuangan }\end{array}$ & Diatas 100 & $\begin{array}{l}\text { - Perluasan } \\
\text { bangunan untuk } \\
\text { menambah } \\
\text { jumlah ruang } \\
\text { yang dapat } \\
\text { disewakan }\end{array}$ \\
\hline $\begin{array}{l}\text { Meningkatkan aktivitas } \\
\text { promosi yang kreatif dan } \\
\text { inovatif }\end{array}$ & $\begin{array}{l}\text { - Jumlah } \\
\text { program } \\
\text { marketing/ } \\
\text { pertahun }\end{array}$ & & Diatas 80 & $\begin{array}{l}\text { - Membuat } \\
\text { perencanaan } \\
\text { keuangan dan } \\
\text { perencanaan } \\
\text { pemasaran }\end{array}$ \\
\hline \multicolumn{5}{|c|}{ PERSPEKTIF PERTUMBUHAN DAN PEMBELAJARAN } \\
\hline $\begin{array}{l}\text { Mengingkatkan } \\
\text { komitmen dan loyalitas } \\
\text { karyawan }\end{array}$ & $\begin{array}{l}\text { - Tingkat } \\
\text { kepuasan } \\
\text { personel } \\
\text { karyawan } \\
\text { - Tingkat } \\
\text { kehadiran } \\
\text { karyawan }\end{array}$ & $\begin{array}{l}\text { - Survey kepuasan } \\
\text { karyawan } \\
\text { - Turnover karyawan } \\
\text { - Laporan absesnsi } \\
\text { karyawan } \\
\text { - Perbandingan total } \\
\text { pendapatan PT }\end{array}$ & Diatas 80 & $\begin{array}{l}\text { - Meningkatkan } \\
\text { komunikasi } \\
\text { dengan pihak } \\
\text { manajemen } \\
\text { - Membuat SOP } \\
\text { perusahan yang } \\
\text { jelas }\end{array}$ \\
\hline $\begin{array}{l}\text { Meningkatkan kualitas } \\
\text { dan kapabilitas karyawan }\end{array}$ & $\begin{array}{l}\text { - Produktivitas } \\
\text { karyawan }\end{array}$ & $\begin{array}{l}\text { Cipta Paramula } \\
\text { Sejati dengan } \\
\text { jumlah karyawan }\end{array}$ & Diatas 80 & $\begin{array}{l}\text { - Menerapkan } \\
\text { sistem reward } \\
\text { and punishment }\end{array}$ \\
\hline $\begin{array}{l}\text { Optimalisasi penggunaan } \\
\text { teknologi untuk } \\
\text { penunjang operasional } \\
\text { perusahaan }\end{array}$ & $\begin{array}{l}\text { - Jumlah } \\
\text { visitor yang } \\
\text { melakukan } \\
\text { kunjungan ke } \\
\text { website } \\
\text { perusahaan } \\
\end{array}$ & - Website perusahaan & Diatas 80 & \\
\hline
\end{tabular}

Sumber: Data primer diolah 2017 


\section{Pembobotan BSC}

Pembobotan terhadap sasaran strategis dan KPI dilakukan untuk mengukur seberapa jauh tingkat kontribusi dari masing-masing perspektif pada BSC. Perhitungan pembobotan BSC dilakukan dengan metode paired comparison berdasarkan pada hasil penilaian yang dilakukan oleh pihak manajemen perusahaan. Hasil pembobotan BSC menggunakan bentuk persentase. Berdasarkan pada Tabel 5, terlihat bahwa perspektif keuangan dan pelanggan memiliki nilai bobot yang sama dan lebih tinggi dibandingkan persepektif lainnya. Nilai kepentingan masing-masing persepektif adalah sebagai berikut: persepektif keuangan sebesar 27,78 persen, perspektif pelanggan sebesar 27,78 persen, perspektif proses bisnis internal sebesar 25 persen dan perepektif pembelajaran dan pertumbuhan sebesar 19,44 persen.

Tabel 5. Hasil pembobotan perspektif BSC PT Cipta Paramula Sejati

\begin{tabular}{|c|c|c|c|c|}
\hline & Sasaran Strategis & $\begin{array}{c}\text { Bobot } \\
\text { (Persen) }\end{array}$ & KPI & $\begin{array}{c}\text { Bobot } \\
\text { (Persen) }\end{array}$ \\
\hline \multirow{4}{*}{ 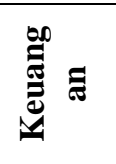 } & Peningkatan posisi keuangan & 9.26 & GPM & 9,26 \\
\hline & Pertumbuhan Profitabilitas & 9.26 & ROI & 4,63 \\
\hline & & & NPM & 4,63 \\
\hline & Meningkatkan perputaran aset & 9.26 & ROA & 9,26 \\
\hline Jumlah & & & & 27,78 \\
\hline \multirow{3}{*}{ 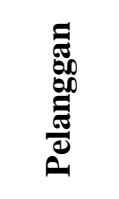 } & Kepuasan pelanggan & 9.26 & $\begin{array}{l}\text { Indeks kepuasan } \\
\text { pelanggan }\end{array}$ & 9,26 \\
\hline & Loyalitas pelanggan & 9.26 & $\begin{array}{l}\text { Rating loyalitas } \\
\text { pelanggan }\end{array}$ & 9,26 \\
\hline & Meningkatkan Brand Image & 9.26 & Brand image & 9,26 \\
\hline Jumlah & & & & 27,78 \\
\hline \multirow{3}{*}{ 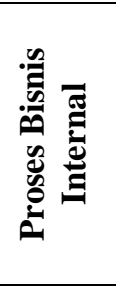 } & $\begin{array}{l}\text { Meningkatkan kualitas } \\
\text { pelayanan }\end{array}$ & 9.72 & $\begin{array}{l}\text { Jumlah keluhan } \\
\text { pelanggan }\end{array}$ & 9,72 \\
\hline & $\begin{array}{l}\text { Optimalisasi pengoperasian } \\
\text { ruangan yang efektif }\end{array}$ & 9.72 & $\begin{array}{l}\text { Jumlah ruang yang } \\
\text { disewakan }\end{array}$ & 9,72 \\
\hline & $\begin{array}{l}\text { Meningkatkan aktivitas } \\
\text { promosi yang kreatif dan } \\
\text { inovatif }\end{array}$ & 5.56 & $\begin{array}{l}\text { Jumlah program } \\
\text { marketing }\end{array}$ & 5,56 \\
\hline Jumlah & & & & 25 \\
\hline \multirow{4}{*}{ 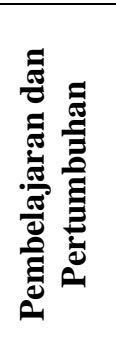 } & $\begin{array}{l}\text { Mengingkatkan komitmen dan } \\
\text { loyalitas karyawan }\end{array}$ & 8.64 & $\begin{array}{l}\text { Tingkat kepuasan } \\
\text { personel karyawan }\end{array}$ & 4,32 \\
\hline & & & $\begin{array}{l}\text { Tingkat kehadiran } \\
\text { karyawan }\end{array}$ & 4,32 \\
\hline & $\begin{array}{l}\text { Meningkatkan kualitas dan } \\
\text { kapabilitas karyawan }\end{array}$ & 8.64 & Produktivitas karyawan & 8,64 \\
\hline & $\begin{array}{l}\text { Optimalisasi penggunaan } \\
\text { teknologi untuk penunjang } \\
\text { operasional perusahaan }\end{array}$ & 2.16 & $\begin{array}{l}\text { Jumlah visitor yang } \\
\text { melakukan kunjungan } \\
\text { ke website }\end{array}$ & 2,16 \\
\hline Jumlah & & & & 19,44 \\
\hline
\end{tabular}

\section{Simulasi Sederhana BSC}

Simulasi sederhana ini dilakukan untuk mengetahui apakah target KPI pada masingmasing perspektif BSC tercapai atau tidak tercapai. Simulasi dilakukan dengan membandingkan antara bobot pencapaian masing- masing KPI dengan nilai bobot dari masing- masing perspektif. Bobot pencapaian diperoleh dari bobot masing-masing KPI dibagi bobot keseluruhan masingmasing persepektif dikali seratus persen. Simulasi dilakukan dengan menggunakan Microsoft Excel, seperti yang ditunjukkan pada Tabel 6. 
Tabel 6. Simulasi sederhana BSC

\begin{tabular}{|c|c|c|c|c|}
\hline KPI & Bobot & $\begin{array}{c}\text { Target } \\
\text { Pencapaian }\end{array}$ & $\begin{array}{c}\text { Target } \\
\text { Tujuan }\end{array}$ & Keterangan \\
\hline GPM & 9,26 & 33,33 & \multirow{4}{*}{27,78} & Tercapai \\
\hline ROI & 4,63 & 16,67 & & Tidak Tercapai \\
\hline NPM & 4,63 & 16,67 & & Tidak Tercapai \\
\hline ROA & 9,26 & 33,33 & & Tercapai \\
\hline Keuangan & 27,78 & & & \\
\hline Indeks kepuasan pelanggan & 9,26 & 33,33 & \multirow[t]{3}{*}{27,78} & Tercapai \\
\hline Rating loyalitas pelanggan & 9,26 & 33,33 & & Tercapai \\
\hline Brand image & 9,26 & 33,33 & & Tercapai \\
\hline Pelanggan & 27,78 & & & \\
\hline Jumlah keluhan pelanggan & 9,72 & 38,89 & \multirow{3}{*}{25} & Tercapai \\
\hline Jumlah ruang yang disewakan & 9,72 & 38,89 & & Tercapai \\
\hline Jumlah program marketing & 5,56 & 22,24 & & Tidak Tercapai \\
\hline Proses Bisnis Internal & 25 & & & \\
\hline Tingkat kepuasan personel karyawan & 4,32 & 22,22 & \multirow{4}{*}{19,44} & Tercapai \\
\hline Tingkat kehadiran karyawan & 4,32 & 22,22 & & Tercapai \\
\hline Produktivitas karyawan & 8,64 & 44,44 & & Tercapai \\
\hline $\begin{array}{l}\text { Jumlah visitor yang melakukan } \\
\text { kunjungan ke website }\end{array}$ & 2,16 & 11,11 & & Tidak Tercapai \\
\hline Pembelajaran dan Pertumbuhan & 19,44 & & & \\
\hline
\end{tabular}

\section{KESIMPULAN}

Hasil penelitian diperoleh berupa 12 sasaran strategis dan empat belas tolak ukur kinerja. Dua belas sasaran strategis adalah peningkatan posisi keuangan, pertumbuhan profitabilitas, peningkatan perputaran aset, kepuasan pelanggan, loyalitas pelanggan, peningkatan Brand Image perusahaan, peningkatan kualitas pelayanan, optimalisasi pengoperasian ruangan yang efektif, peningkatan aktivitas promosi yang kreatif dan inovatif, peningkatan komitmen dan loyalitas karyawan, peningkatan kualitas dan kapabilitas karyawan, optimalisasi penggunaan teknologi untuk penunjang operasional perusahaan. Empat Belas tolak ukur kinerja (KPI) adalah Gross Profit Margin (GPM), Return On Investement (ROI), Net Profit Margin (NPM), Return On Assets (ROA), indeks kepuasan pelanggan, rating loyalitas pelanggan, brand image, jumlah keluhan pelanggan, jumlah ruang yang disewakan, jumlah program marketing pertahun, tingkat kepuasan personal karyawan, tingkat kehadiran karyawan, produktivitas karyawan, jumlah visitor yang melakukan kunjungan ke website perusahaan. Berdasarkan hasil penyusunan BSC pada PT Cipta Paramula Sejati, diperoleh pembobotan untuk masing-masing perspektif BSC adalah sebagai berikut: perspektif keuangan sebesar 27,78 persen, perspektif pelanggan sebesar 27,78 persen, perspektif proses bisnis internal sebesar 25 persen, dan perspektif pembelajaran dan pertumbuhan sebesar 19,44 persen.

\section{DAFTAR PUSTAKA}

Abdel, \& Saed. (2014). The imapct of strategic management on the Jordanian pharmaceutical manufacturing organizations business performance. Irmbrjournal International Review of Management and Busniness Reserch, 3(2)

Arief, H. W. (2007). Perancangan Pengukuran Kinerja PT Mitrarahayu Karyanugraha dengan Pendekatan Balanced Scorecard. Bogor, Indonesia: Institut Pertanian Bogor.

Ayoup, H., Omar, N., Rahman, I. K. A. (2016). Balanced scorecard and strategic alignment: a Malaysian case. International Journal of Economic and Financial Issue, 6(S4), 85-95. 
Chimtengo, S., Mkandawire, K., \& Hanif, R. (2017). An evaluation of performance using the balanced scorecard model for The University of Malawi's Polytecnic. African Journal of Business Management, 11(4), 84-93.

Chung, C. C., Chao, L.C., Chen, C. H. (2016). A balanced scorecard of sustainable management in the Taiwanese bicycle industry: development of performance indicators and importance analysis. MDPI journal Sustainability, 8, 518.

Colliers International. (2016). Colliers Quarterly Q4 2016: Office Sector. Jakarta: Colliers International.

David, F. R. (2006). Manajemen Strategis Konsep. Edisi 10. Ichsan SB, penerjemah; Stefanus R, editor. Salemba Empat. Jakarta. Terjemahan dari: Strategic Management : Concepts and Cases, 10th ed.

Fauziah, I. (2007). Perancangan dan Pengukuran Kinerja dengan Pendekatan Balanced Scorecard di PT Karisma Dutawasera Regional Bandung. Bogor, Indonesia: Institut Pertanian Bogor.

Kaplan, S. R., \& Norton, D. P. (2000). Balanced Scorecard: Menerapkan Strategi Menjadi Aksi. Peter R, penerjemah; Yati Sumiharti dan Wisnu Chandra, editor. Erlangga. Jakarta. Terjemahan dari Balanced Scorecard Translating Strategy Into Action.

Kinnear, T. C., \& Taylor, J. R. (1991). Marketing Research: An Applied Approach Fourth Edition. New York: McGraw - Hill, Inc

Matello, M., Watson, J. G., \& Fischer, M. J. (2016). Implementing a balanced scorecard in a not-for-profit organization. Journal of Business and Economic Reseach, 14(3)

Niven, P. R. (2006). Balanced Scorecard: Step by Step. New Jersey: John and Sons, Inc.

Suara. (2018). Pasokan Ruang Perkantoran Jakarta Terbesar di 2018. www.suara.com. 4 April 2018; [diunduh 1 September 2018]: Jakarta.

Trends. (2007). Southeast Asia: Home and Apartment Vol 22 No 13. Singapore: Trends Publishing Singapore Ltd.

Trijaya, F. (2010). Apartemen dan Pusat Perbelanjaan di Jakarta Pusat. Jakarta, Indonesia: Universitas Bina Nusantara.

Wulandari, R. (2016). Perancangan Sistem Balanced Scorecard pada Perusahaan Properti (Studi Kasus: Elang Group). Bogor, Indonesia: Institut Pertanian Bogor 